\title{
THE EFFECTS OF HEAVY METAL CONCENTRATIONS IN THE ÇANAKKALE STRAIT (TURKEY): MORPHOLOGICAL DIFFERENCES IN THE HOLOCENE FORAMINIFERAL ASSEMBLAGES
}

\author{
Zeki Ünal Yümün \\ Department of Environmental Engineering, Faculty of Çorlu Engineering, University of Namık Kemal \\ University, Çorlu/ Tekirdăg, Turkey \\ yumun@gmail.com
}

\begin{abstract}
In this study have been investigated the effects of heavy metals on foraminiferal assemblages in Çanakkale Strait. For this purpose, core samples were collected from 12 locations in the Çanakkale Strait. With the consideration of the faunal and sedimentological properties of the samples have been showed that the Çanakkale Strait is completely has rich marine foraminifer populations. The abnormalities observed of foraminifer the yellow and/or black colored shells have been due to natural and anthropogenic ecological pollution. In the present study the average values were calculated to bring to light the heavy metal pollution.

In this study have been investigated the effects of heavy metals on foraminiferal assemblages in Çanakkale Strait. For this purpose, core samples were collected from 12 locations in the Çanakkale Strait. With the consideration of the faunal and sedimentological properties of the samples have been showed that the Çanakkale Strait is completely has rich marine foraminifer populations. The abnormalities observed of foraminifer the yellow and/or black colored shells have been due to natural and anthropogenic ecological pollution. In the present study the average values were calculated to bring to light the heavy metal pollution.

Especially in the ports, Morphological abnormalities and the color changes have been seen at shales of benthic foraminifer genera and species. Morphological changes were observed in Elphidium crispum, Massilina secans, and Ammonia compacta foraminifer species in the core samples taken in areas where ports in the Çanakkale Strait. Especially Morphological changes were observed in Elphidium crispum, Massilina secans, and Ammonia compacta foraminifer species in the core samples taken in areas where ports in the Çanakkale Strait. The average nvalue measured in Ports have been higher than the critical value, indicating that heavy metal concentrations affect the foraminifera.
\end{abstract}

Keywords: Heavy metals, Marmara Sea, Çanakkale, Çanakkale Strait, Foraminifera. 


\section{Introduction}

This study determined the concentrations of heavy metals in the Recent sediments in the Çanakkale Strait (west of Şarköy) and investigated the effects of elements on foraminiferal assemblages (Figure 1). Artüz (2002) explored the ecological changes observed in the Marmara Sea and their possible causes and assessed the main points of the hydrography [1]. The Change of ecological characteristics, and development of pollution in over time have progresed in the Sea of Marmara and Strait system. Balkıs and Çağatay (2001) defined that metal accumulations come from natural and anthropogenic sources and investigated the mechanisms of sediment formation [2]. Avşar et al. (2006) identified the current foraminiferal assemblages living in the Erdek Gulf [3]. Meriç et al. (2008) investigated the influence of environmental conditions on the Foraminifer and Ostracod community around the marine resources of Harmantaşı region (Saroz Gulf) [4].

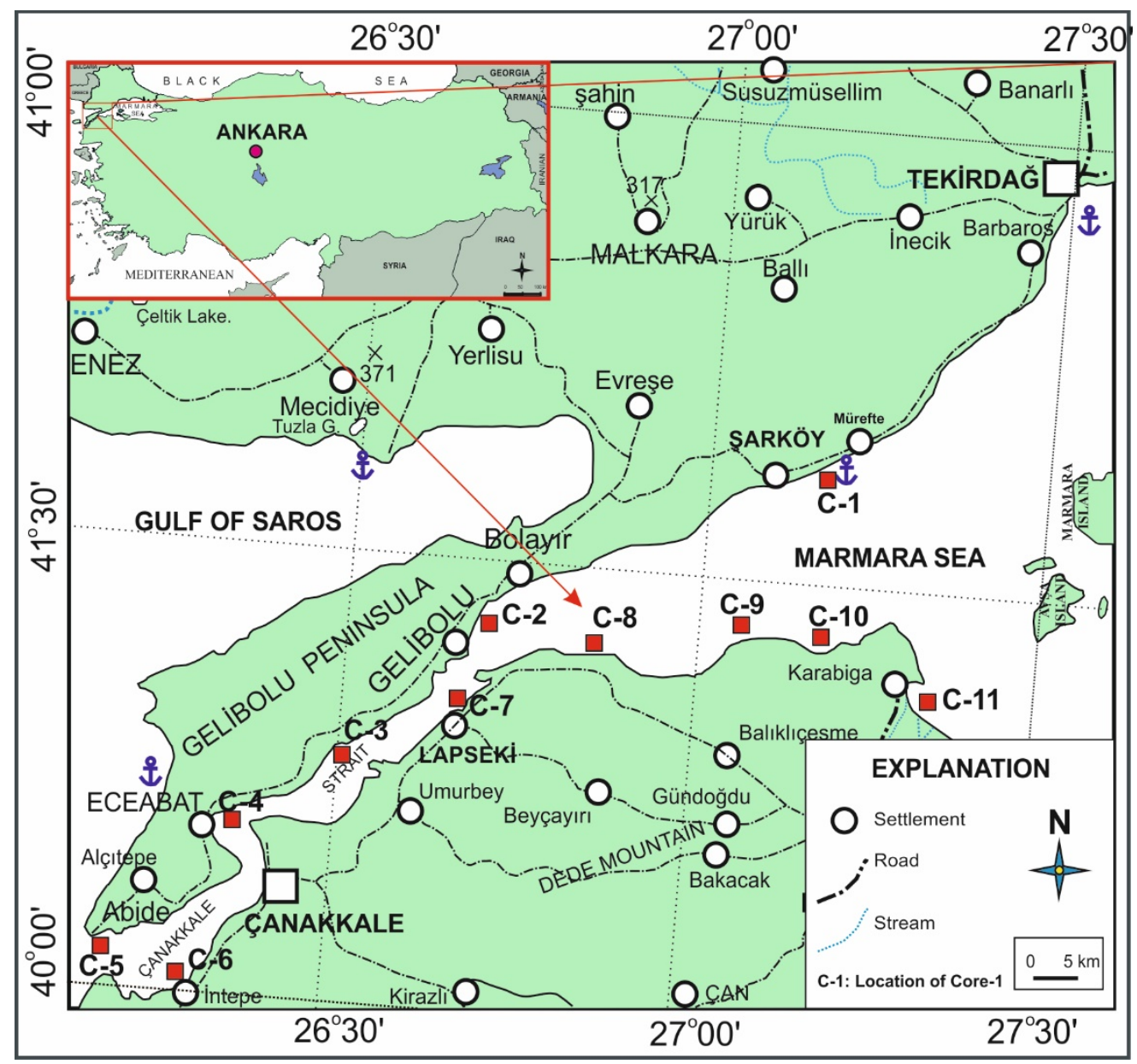

Figure 1. Location map of investigation area and core sample location.

Meriç et al. (2009) examined the geochemistry of the sediment distribution with the factors controlling the current benthic foraminifera, ostracod, mollusk community of the Çanakkale Strait. 73 genus and 118 species belonging to the foraminifera community were identified in the study [5]. Kurc1-Elmas (2013) investigated the foraminiferal assemblages in the western Marmara Sea. All the foraminiferal assemblages that lived from the Pleistocene to the present in the western part of the Sea of Marmara were identified with four drill core samples. Recent 
foraminiferal assemblages have been defined by examining core samples taken from 43 locations [6].

\section{Material and Methods}

The current sediment samples were collected from three different locations in the Çanakkale Strait: Şarköy (Core-1), Gelibolu (Core-2), Burhanlı (Core-3), Eceabat (Core-4), Seddülbahir (Core-5), Kumkale (Core-6), Çanakkale (Core-7), Lapseki (Core-8), Şevketiye (Core-9), Kemer (Core-10), Aksaz (Core-11), Kara Biga (Core-12) (Fig. 1 and Table 1). The samples collected were transported to the laboratory protected by sun-proof core boxes. A total of 60 samples from the other core samples, were examined (Table 1).

Table 1. Geographic coordinates and other properties of Core Samples.

\begin{tabular}{|l|c|c|c|c|}
\hline \multicolumn{1}{|c|}{ Core No } & $\begin{array}{c}\text { Water } \\
\text { Depth } \\
\text { (m) }\end{array}$ & $\begin{array}{c}\text { Sample } \\
\text { Length } \\
\text { (m) }\end{array}$ & \multicolumn{2}{c|}{$\begin{array}{c}\text { Coordinates } \\
\text { (WGS-84, 6 }\end{array}$} \\
\cline { 3 - 5 } & & & X & Y \\
\hline Core-1: Şarköy & 8,5 & 0,55 & $4494712.51 \mathrm{~m} \mathrm{~K}$ & $511453.76 \mathrm{~d} \mathrm{D}$ \\
\hline Core-2: Gelibolu & 11,2 & 1,0 & $4473011.64 \mathrm{~m} \mathrm{~K}$ & $472991.68 \mathrm{~d} \mathrm{D}$ \\
\hline Core-3: Burhanlı & 6,5 & 1,0 & $4461803.71 \mathrm{~m} \mathrm{~K}$ & $462984.25 \mathrm{~d} \mathrm{D}$ \\
\hline Core-4: Eceabat & 11,5 & 0,85 & $4448302.62 \mathrm{~m} \mathrm{~K}$ & $445642.12 \mathrm{~d} \mathrm{D}$ \\
\hline Core-5: Seddülbahir & 7,0 & 0,90 & $4432407.18 \mathrm{~m} \mathrm{~K}$ & $430862.01 \mathrm{~d} \mathrm{D}$ \\
\hline Core-6: Kumkale & 8,0 & 0,65 & $4428186.18 \mathrm{~m} \mathrm{~K}$ & $437163.65 \mathrm{~d} \mathrm{D}$ \\
\hline Core-7: Çanakkale & 12,0 & 1,2 & $4439870.00 \mathrm{~m} \mathrm{~K}$ & $448363.00 \mathrm{~d} \mathrm{D}$ \\
\hline Core-8: Lapseki & 9,5 & 0,75 & $4467132.36 \mathrm{~m} \mathrm{~K}$ & $473234.69 \mathrm{~d} \mathrm{D}$ \\
\hline Core-9: Şevketiye & 8,5 & 0,60 & $4472579.00 \mathrm{~m} \mathrm{~K}$ & $489029.00 \mathrm{~d} \mathrm{D}$ \\
\hline Core-10: Kemer & 5,5 & 0,85 & $4476904.30 \mathrm{~m} \mathrm{~K}$ & $506364.34 \mathrm{~d} \mathrm{D}$ \\
\hline Core-11: Aksaz & 7,5 & 0,85 & $4476503.96 \mathrm{~m} \mathrm{~K}$ & $517048.70 \mathrm{~d} \mathrm{D}$ \\
\hline Core-12: Kara Biga & 9,5 & 0,95 & $4472285.13 \mathrm{~m} \mathrm{~K}$ & $526802.20 \mathrm{~d} \mathrm{D}$ \\
\hline
\end{tabular}

Wet sieve analysis was used for the current sediment samples to separate foraminifers from sediments. Firstly in the sieve analysis, 10\% H2O 2 was added to 15 grams of each sediment sample. Second, the samples were kept for 24 hours and washed with water in a $0.125 \mathrm{~mm}$ sieve. Following the washing process, samples were dried for 12 to 24 hours at $60^{\circ} \mathrm{C}$ and foraminifers were identified with a binocular microscope. The microphotographs of the foraminifer shells were taken with a Binokular Microscope (SEM) at the Scientific and Technological Research and Application Center of Namık Kemal University (NABİLTEM).

The element analyses (Fe, Zn, Al, Mn, As, B, Co, Cr, Cu, Ni, Sb, Na, Mg, K, Ca, P, Pb, Hg, $\mathrm{Cd}, \mathrm{Ag}, \mathrm{Bi}, \mathrm{Mo}, \mathrm{Pt}, \mathrm{Sn}, \mathrm{Se})$ were carried out at Namık Kemal University Scientific and Technological Research Application and Research Center (NABILTEM). The sediment samples to be analyzed were first dried and then pounded with a mortar to separate the granules, and $0.5 \mathrm{~g}$ was taken from the samples. Then $12 \mathrm{~mL}$ of $\mathrm{HNO}_{3}$ and $4 \mathrm{~mL}$ of $\mathrm{HCl}$ were added to the samples, which were put into combustion tubes and burned at $98{ }^{\circ} \mathrm{C}$ for 1 hour and $200{ }^{\circ} \mathrm{C}$ for 1.5 hours. Once the lids of the cooling tubes were opened in the furnace, the samples were diluted to $50 \mathrm{~mL}$ with ultra-pure water filtered with filter papers. The prepared sample was placed on the measuring unit of the ICP-OES instrument, and measurements were carried out. 


\section{Results}

\subsection{Foraminiferal assemblages}

Core samples from Çanakkale Strait were studied, while foraminiferal assemblages of seafloor sediments from Marmara Sea (12) were detected. A rich foraminiferal assemblage (Adelosina duthiersi Schlumberger, Adelosina mediterranensis (Le Calvez, J. and Y.), Adelosina pulchella (d'Orbigny), Ammonia compacto Hofker, Ammonia parkinsionia (d'Orbigny), Ammonia tepida Cushman, Anomalinoides rubiginosus (Cushman), Bulimina aculeata d'Orbigny, Bulimina elongata d'Orbigny , Brizalina spathulata (Williamson), Casidulina teretis Silvestri, Cibicidoides mundulus (Walker \& Jacob), Cycloforina villafrance Le Calvez \& Le Calvez, Cycloforina concorta (d'Orbigny), Elphidium crispum (Linné), Elphidium complanatum (d'Orbigny), Elphidium macellum (Fichtel \& Moll), Hyrokkin sarcophaga (Freiwald and Schönfeld), Lobatula lobatula (Walker \& Jacob), Massilina secans (d'Orbigny), Melonis pompilioides (Fichtel \& Moll), Miliolinella subrotunda (Montagu), Nonionella turgida (Williamson), Peneroplis pertusus (Forskål), Planorbulina mediterranensis d'Orbigny, Polymorphina sp., Pygro elongata (d'Orbigny), Pygro inornata (d'Orbigny), Quinqueloculina bidentata d'Orbigny, Quinqueloculina disparilis d'Orbigny, Quinqueloculina jugosa Cushman, Quinqueloculina seminula (Linné), Rosalina bradyi d'Orbigny, Rectuvigerina multicostata (Cushman \& Jarvis), Spiroloculina excavata d'Orbigny, Spiroloculina tenuiseptata Brady, Textularia bocki Höglund, Textularia truncata Höglund) was determined from the Marmara core samples (Table 3 and Plate 1-2). In this study, 24 foraminifer species and 38 foraminifera species were identified No significant color changes or morphological abnormalities were observed in general in the core samples taken from the western Çanakkale Strait.

Table 2. Foraminiferal assemblages of core samples of western Marmara Sea (Cores 1-12).

\begin{tabular}{|c|c|c|c|c|c|c|c|c|c|c|c|c|}
\hline Foraminifera Species & U⿺ & نٌ & نُ & ن⿺ & نٌ & نُ & & $\begin{array}{l}\infty \\
\dot{d} \\
\dot{\vdots} \\
0\end{array}$ & ḋ̀ & $\frac{\mathscr{d}}{d}$ & 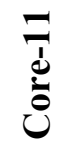 & ْ̃ \\
\hline Adelosina duthiersi & & & & & 1 & & & & & & & \\
\hline $\begin{array}{l}\text { Adelosina } \\
\text { mediterranensis }\end{array}$ & & 4 & 27 & & & & 20 & & & & & \\
\hline Adelosina pulchella & & 5 & & & & & & & & & & \\
\hline Ammonia compacto & 1 & 52 & 50 & & & 3 & 22 & & 2 & 5 & & \\
\hline $\begin{array}{l}\text { Ammonia } \\
\text { parkinsioniana }\end{array}$ & 3 & 4 & & 1 & 3 & & & 2 & & & 1 & \\
\hline Ammonia tepida & & & & & & & 15 & & & 2 & 2 & \\
\hline $\begin{array}{l}\text { Anomalinoides } \\
\text { rubiginosus }\end{array}$ & & 13 & & & & & & & & & & \\
\hline Bulimina aculeata & & 2 & & & & & & & & & & \\
\hline Bulimina elongata & & & & & & & & & & 8 & & \\
\hline Brizalina spathulata & & & & & & & & & & 7 & & \\
\hline Casidulina teretis & & 3 & & & & & & & & 28 & & \\
\hline Cibicidoides mundulus & & & & & & & & & & 3 & & \\
\hline Cycloforina villafrance & & & & 1 & & & 3 & & & & & \\
\hline Cycloforina concorta & & 1 & 10 & & & & & 5 & & & 1 & \\
\hline Elphidium crispum & & & 98 & & 15 & 3 & 25 & 2 & 2 & & & 1 \\
\hline Elphidium complanatum & & & & & 10 & 1 & 18 & 2 & & & & \\
\hline
\end{tabular}




\begin{tabular}{|c|c|c|c|c|c|c|c|c|c|c|c|c|}
\hline Foraminifera Species & U⿺ & 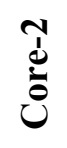 & نُ & ن⿺辶 & نُ & $\begin{array}{l}0 \\
\dot{d} \\
\dot{0} \\
0\end{array}$ & U⿺尢丶 & $\begin{array}{l}\infty \\
\stackrel{d}{0} \\
\dot{0}\end{array}$ & $\begin{array}{l}\hat{d} \\
\stackrel{d}{0}\end{array}$ & $\frac{0}{\stackrel{d}{d}}$ & نَ & ن̃ \\
\hline Elphidium macellum & & 1 & & & & & & & & 3 & 3 & \\
\hline Hyrokkin sarcohaga & & & & & & & & & & 2 & & \\
\hline Lobatula lobatula & 1 & & 8 & & & 1 & & & & & & \\
\hline Massilina secans & 2 & & & & 3 & & 6 & & 1 & & & \\
\hline Melonis pompilioides & & 7 & & & 2 & & & & & 9 & & 1 \\
\hline Miliolinella subrotunda & & & & & & & 12 & & & & & \\
\hline Nonionella turgida & & 1 & & & & & & & & & & \\
\hline Peneroplis planatus & & & & & 2 & & & & & & & \\
\hline $\begin{array}{l}\text { Planorbulina } \\
\text { mediterranensis }\end{array}$ & & 1 & & & & & 4 & & & & & \\
\hline Polymorphina sp. & & 2 & & & & & & & & & & \\
\hline Pygro elongata & & & & & & & & 2 & & & & \\
\hline Pygro inornata & & 1 & & & & & & & & 1 & & \\
\hline $\begin{array}{l}\text { Quinqueloculina } \\
\text { bidentata }\end{array}$ & & & & & & & & 3 & & & & \\
\hline $\begin{array}{l}\text { Quinqueloculina } \\
\text { disparilis }\end{array}$ & & & & & & & & & 1 & & & \\
\hline Quinqueloculina jugosa & & & & & & 1 & & & & & & \\
\hline $\begin{array}{l}\text { Quinqueloculina } \\
\text { seminula }\end{array}$ & 5 & 11 & 35 & & 12 & 5 & 15 & & 2 & 2 & 4 & 2 \\
\hline Rosalina bradyi & & & 7 & & & & & & & & & \\
\hline $\begin{array}{l}\text { Rectuvigerina } \\
\text { multicostata }\end{array}$ & & 3 & & & & & & & & & & \\
\hline Spiroloculina excavata & & 1 & 7 & & & & & & & & & \\
\hline $\begin{array}{l}\text { Spiroloculina } \\
\text { tenuiseptata }\end{array}$ & & & & & & & & & & 2 & & \\
\hline Textularia bocki & & 2 & 3 & & & 5 & & & & & & \\
\hline Textularia truncata & & & & & & & & & & 2 & & \\
\hline
\end{tabular}

Color changes and morphological defects were generally observed in the shell structures of the foraminifera obtained from the core samples taken from the Çanakkale Striat (Core 2, 7 and 8) where near the ports.

\subsection{Geochemical analyses}

The core samples were separated into 10-cm sections, and heavy metal analyses of 60 samples of 15 grams were carried out with the ICP-OS device. The results of the heavy metal analyses carried out at Namık Kemal University Scientific and Technological Research Application and Research Center (NABILTEM) are given in Tables 4. The concentrations of 27 elements (Fe, $\mathrm{Zn}, \mathrm{Al}, \mathrm{Mn}, \mathrm{As}, \mathrm{B}, \mathrm{Co}, \mathrm{Cr}, \mathrm{Cu}, \mathrm{Ni}, \mathrm{Sb}, \mathrm{Na}, \mathrm{Mg}, \mathrm{K}, \mathrm{Ca}, \mathrm{P}, \mathrm{Pb}, \mathrm{Hg}, \mathrm{Cd}, \mathrm{Ag}, \mathrm{Bi}, \mathrm{Cd}, \mathrm{Mo}, \mathrm{Pb}, \mathrm{Pt}$, $\mathrm{Sn}, \mathrm{Se})$ in the geochemical analyses were determined. The average values of core samples were calculated by using the average values obtained for each core sample (Table 4). The proportions of each element concentration in the core samples to the average value were calculated. The mean values of the heavy metals of the Marmara Sea. 
$\mathrm{Al}, \mathrm{Cu}, \mathrm{K}$ and $\mathrm{P}$ at samples taken from the Çanakkale Strait high from average value of Marmara Sea. The average values calculated for the core samples taken from the Çanakkale Strait were compared with the number of foraminifer genus and species detected in the same samples (Table 3 and Figure 2).

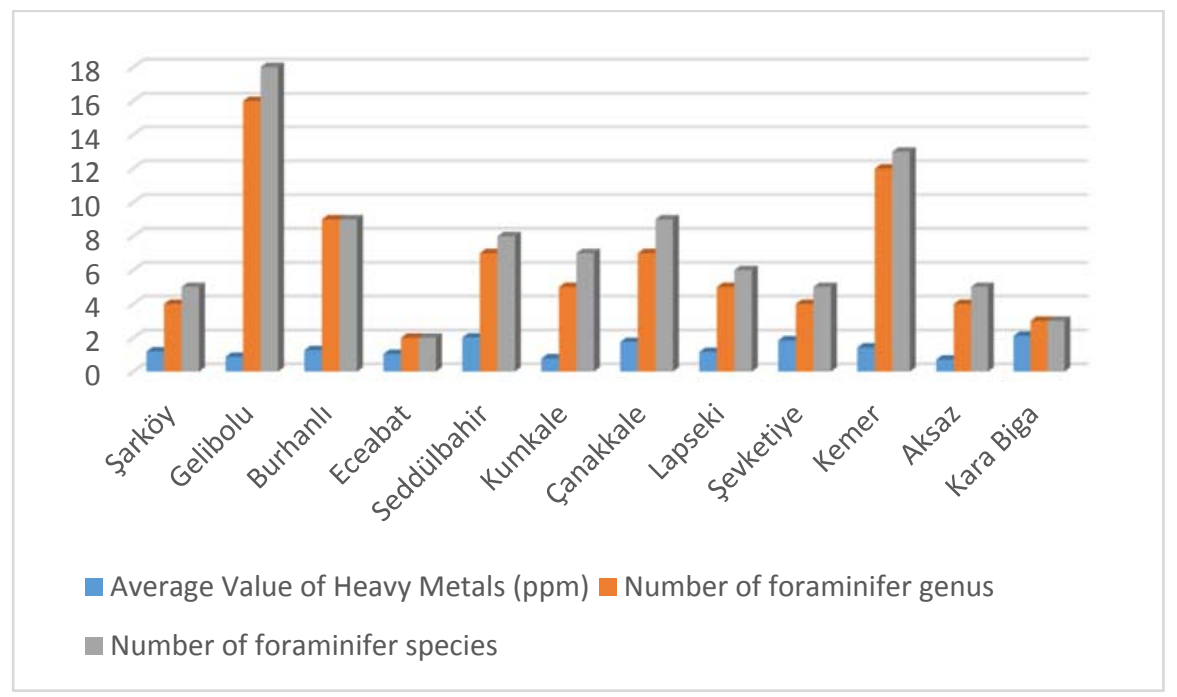

Figure 2. Corelation graphic of average value with number of foraminifer genus and species

As seen in Figure 2 the number of foraminifer genus and species was low at the locations where the PI values were high. Foraminifer genus and species were high at Other locations. 
Table 3. Heavy metal consantration and Pollution Index of core samples.

\begin{tabular}{|c|c|c|c|c|c|c|c|c|c|c|c|c|c|c|c|c|c|c|c|c|}
\hline Somp & $\mathbf{F e}$ & $\mathbf{Z n}$ & Al & Mn & As & B & Cd & Co & $\mathrm{Cr}$ & $\mathrm{Cu}$ & $\mathbf{N i}$ & $\mathbf{P b}$ & Pt & Sb & $\mathrm{Na}$ & Mg & $\mathbf{K}$ & $\mathrm{Ca}$ & $\mathbf{P}$ & $\begin{array}{c}\text { Average } \\
\text { Value }\end{array}$ \\
\hline & ppm & ppm & ppm & ppm & ppm & ppm & ppm & ppm & ppm & ppm & ppm & ppm & ppm & ppm & ppm & ppm & ppm & ppm & ppm & ppm \\
\hline Core-1: Şarköy & 14748.80 & 28.95 & 5031.40 & 326.70 & 4.87 & 18.00 & 0.46 & 7.87 & 56.66 & 50.81 & 61.57 & 9.86 & 0.62 & 0.31 & 2309.10 & 5329.50 & 2528.10 & 41816.60 & 4181.66 & 1.19 \\
\hline Core-2: Gelibolu & 17874.70 & 25.95 & 7754.60 & 323.00 & 4.26 & 14.68 & 0.51 & 8.41 & 32.50 & 27.34 & 40.89 & 7.18 & 0.52 & 0.57 & 3707.40 & 3062.70 & 5007.80 & 26199.10 & 2619.91 & 0.87 \\
\hline Core-3: Burhanlı & 8931.40 & 15.60 & 2827.50 & 292.30 & 1.06 & 6.49 & 0.19 & 4.17 & 35.30 & 58.58 & 26.17 & 13.77 & 0.46 & 0.31 & 2035.90 & 2262.90 & 1235.50 & 59634.70 & 5963.47 & 1.27 \\
\hline Core-4: Eceabat & 9621.10 & 21.10 & 3719.40 & 320.60 & 5.02 & 15.23 & 0.15 & 4.66 & 23.25 & 22.10 & 27.25 & 11.59 & 0.38 & 0.70 & 511.90 & 2948.00 & 1508.90 & 50185.80 & 5018.58 & 1.04 \\
\hline $\begin{array}{l}\text { Core-5: } \\
\text { Seddülbahir }\end{array}$ & 17638.60 & 72.35 & 7097.70 & 316.80 & 5.42 & 68.77 & 0.88 & 8.32 & 50.88 & 0.00 & 53.52 & 41.02 & 0.69 & 0.79 & 7975.50 & 5811.90 & 6891.10 & 95372.90 & 9537.29 & 2.02 \\
\hline Core-6: Kumkale & 31824.00 & 67.65 & 11382.70 & 381.30 & 1.78 & 18.57 & 0.00 & 3.99 & 17.74 & 10.68 & 17.52 & 3.82 & 0.30 & 0.14 & 2592.60 & 4616.00 & 7263.80 & 19784.00 & 1978.40 & 0.78 \\
\hline $\begin{array}{l}\text { Core-7: } \\
\text { Çanakkale }\end{array}$ & 51520.40 & 59.20 & 10435.20 & 408.20 & 0.00 & 8.78 & 3.71 & 39.69 & 158.27 & 106.90 & 116.75 & 14.88 & 3.06 & 0.79 & 2105.50 & 9180.80 & 6806.90 & 19311.50 & 1931.15 & 1.75 \\
\hline Core-8: Lapseki & 12051.60 & 20.35 & 5697.30 & 119.40 & 2.96 & 21.11 & 0.32 & 4.71 & 26.45 & 77.58 & 39.13 & 9.60 & 0.28 & 0.22 & 4530.60 & 2417.20 & 3220.20 & 42467.40 & 4246.74 & 1.16 \\
\hline Core-9: Şevketiye & 33819.70 & 106.35 & 10611.60 & 507.90 & 10.27 & 53.33 & 2.13 & 14.48 & 72.22 & 113.77 & 54.39 & 25.00 & 1.90 & 0.85 & 8911.80 & 4960.40 & 7638.60 & 38509.70 & 3850.97 & 1.84 \\
\hline Core-10: Kemer & 7654.90 & 1.05 & 3210.70 & 242.10 & 9.08 & 20.05 & 0.98 & 12.05 & 32.05 & 64.77 & 27.24 & 30.75 & 1.00 & 1.30 & 2646.40 & 2658.60 & 2120.60 & 58358.70 & 5835.87 & 1.42 \\
\hline Core-11: Aksaz & 9891.80 & 47.75 & 3714.30 & 115.80 & 1.74 & 6.23 & 0.30 & 3.62 & 13.85 & 55.11 & 14.36 & 20.51 & 0.54 & 0.33 & 2503.10 & 1283.80 & 2195.00 & 19295.50 & 1929.55 & 0.71 \\
\hline $\begin{array}{ll}\begin{array}{l}\text { Core-12: } \\
\text { Biga }\end{array} & \text { Kara } \\
\end{array}$ & 20948.40 & 128.10 & 7484.20 & 305.10 & 5.81 & 21.77 & 1.42 & 8.44 & 48.49 & 124.12 & 36.08 & 375.76 & 1.32 & 1.03 & 5341.40 & 3081.30 & 4803.90 & 49077.90 & 4907.79 & 2.11 \\
\hline $\begin{array}{l}\text { Average Value of } \\
\text { Core }\end{array}$ & 19710.45 & 49.53 & 6580.55 & 304.93 & 4.36 & 22.75 & 0.92 & 10.03 & 47.31 & 59.31 & 42.90 & 46.98 & 0.92 & 0.61 & 3764.27 & 3967.76 & 4268.37 & 43334.48 & 4333.45 & 1.35 \\
\hline $\begin{array}{l}\text { Average Value of } \\
\text { all Marmara Sea }\end{array}$ & 29833.36 & 81.11 & 17067.92 & 404.45 & 23.44 & 61.99 & 0.92 & 34.60 & 126.46 & 15.69 & 107.95 & 46.98 & 0.92 & 3.27 & 6068.33 & 4797.92 & 3820.05 & 66019.97 & 402.84 & 1 \\
\hline
\end{tabular}




\section{Conclusion}

This study investigated the effects of heavy metals on foraminifera in the recent sediments of the Çanakkale Strait. For this purpose, the current sediment samples were collected from twelve different locations in the Çanakkale Strait: Şarköy (Core-1), Gelibolu (Core-2), Burhanlı (Core3), Eceabat (Core-4), Seddülbahir (Core-5), Kumkale (Core-6), Çanakkale (Core-7), Lapseki (Core-8), Şevketiye (Core-9), Kemer (Core-10), Aksaz (Core-11), Kara Biga (Core-12)). These core samples were studied and foraminiferals from seafloor sediments of Marmara Sea were detected. A rich foraminiferal assemblage (Adelosina duthiersi, Adelosina mediterranensis, Adelosina pulchella, Ammonia compacto, Ammonia parkinsionia, Ammonia tepida, Anomalinoides rubiginosus, Bulimina aculeata, Bulimina elongata, Brizalina spathulata, Casidulina teretis, Cibicidoides mundulus, Cycloforina villafrance, Cycloforina concorta, Elphidium crispum, Elphidium complanatum, Elphidium macellum, Hyrokkin sarcophaga, Lobatula lobatula, Massilina secans, Melonis pompilioides, Miliolinella subrotunda, Nonionella turgida, Peneroplis pertusus, Planorbulina mediterranensis, Polymorphina sp., Pygro elongata, Pygro inornata, Quinqueloculina bidentata, Quinqueloculina disparilis, Quinqueloculina jugosa Cushman, Quinqueloculina seminula, Rosalina bradyi, Rectuvigerina multicostata, Spiroloculina excavata, Spiroloculina tenuiseptata, Textularia bocki, Textularia truncata) was determined from the Marmara core samples. In this study, 24 foraminifer genus and 38 foraminifer species were identified. No significant color changes or morphological abnormalities were observed in general in the core samples taken from the western Çanakkale Strait. Color changes and morphological defects were generally observed in the shell structures of the foraminifera obtained from the core samples taken from the Çanakkale Striat (Core 2, 7 and 8) where near the ports.

The concentrations of 27 elements in the geochemical analyses were determined. The average values of core samples were calculated by using the average values obtained for each core sample. The proportions of each element concentration in the core samples to the average value were calculated. Al, $\mathrm{Cu}, \mathrm{K}$ and $\mathrm{P}$ at samples taken from the Çanakkale Strait high from average value of Marmara Sea. The Average Values calculated for the Çanakkale Strait core samples were compared with the number of foraminifer genus and species detected in the same samples. Number of foraminifer genus and species was low at the locations where the Average Values were high. Also Foraminifer genus and species were high at Other locations where Average value were low. It has been found that the number of foraminifera is high in places where water flow is not excessive and water temperature is high (location of ports).

\section{Acknowledgements}

The author thanks to Yümün Mühendislik Limited Company for their studies on collection of samples from the sea, and Melike Önce, and Sevinç Yümün for the preparation of the samples in the laboratory and for the separation studies of other fossils.

\section{Reference}

[1] Artüz M.L., "Marmara ve Boğazların Ekolojisi ve Değişimler” (paper presented at the annual meeting for the Balikesir University Marine Technology Symposium. Proceedings Book, 2002). [In Turkish] 
[2] Balkıs, N., Çağatay, M.N., "Factors controlling metal distribution in the surface sediments of the Erdek Bay, Sea of Marmara, Turkey" Environment International, 27 (2001): 1-13.

[3] Avşar, N., Aksu, A., Dinçer, F., "Erdek Körfezi (GB Marmara Denizi) bentik foraminifer toplulukları," Journal of the Earth Sciences Application and Research Centre of Hacettepe University, 27 (3), (20016): 125-141.

[4] Meriç, E., Avşar, N., Nazik, A., Tunoğlu, C., Yokeş, Barut, İ., Yücesoy-Eryilmaz, Beril, T., Görmüş, M., Öncel, M.S., Orak, H., Kam, E., Dinçer, F., "Harmantaşı Mevkii (Saros Körfezi-Kuzey Ege Denizi) Deniz İçi Kaynakları Çevresindeki Foraminifer ve Ostrakod Topluluğuna Bu Alandaki Çevresel Koşulların Etkisi” The Journal of Turkey Mineral Research and Exploration, 136 (1) (2008). [In Turkish]

[5] Meriç, E., Avşar, N., Nazik, A., Yokeş, B., Ergin, E., Eryilmaz, M., Yücesoy-Eryilmaz, F., Gökaşan, E., Suner, F., Tur, H., Aydin, Ş. and Dinçer, F., 'Çanakkale Boğazı'nın Güncel Bentik Foraminifer, Ostrakod, Mollusk Topluluğunu Denetleyen Faktörler ile Çökel Dağılımının Jeokimyası,”, Geol. Bull. Turkey. 52 (2) (2009). [In Turkish].

[6] Kırc1-Elmas, E., "Benthic Foraminiferal Distribution (Living And Dead) From A Permanently Stratified Marginal Sea (Marmara Sea, Turkey)” Journal of Foraminiferal Research, 43,4 (2013): 340-360. 


\section{Explanations of Plate-1}

\section{PLATES}

Figure 1: Elphidium crispum, Sample: Core 9, 8.50-8.60 m

Figure 2: Elphidium crispum, Sample: Core 6, 8.00-8.10 m

Figure 3-4: Elphidium macellum, Sample: Core 5, 7.10-7.20 m

Figure 5-6: Elphidium macellum, Sample: Core 5, 7.20-7.30 m

Figure 7: Elphidium complanatum, Sample: Core 9, 8.60-8.70 m

Figure 8: Elphidium complanatum, Sample: Core 5, 7.30-7.40 m

Figure 9-10: Elphidium advenum, Sample: Core 6, 8.10-8.20 m

Figure 11-12: Ammonia compacta, Sample: Core 2, 8.60-8.70 m

Figure 13-14: Ammonia compacta, Sample: Core 8, 9.50-9.60 m

Figure 15-16: Ammonia tepida, Sample: Core 4, 11.50-11.60 m

Figure 17-18: Rotalinoides rubiginosus ,Sample: Core 1, 8.70-8.80 m

Figure 19-20: Rotalinoides rubiginosus, Sample: Core 9, 8.60-8.70 m

Figure 21-22: Melonis pompilioides, Sample: Core 1, 8.50-8.60 m

Figure 23-24 : Lobatula lobatula, Sample: Core 1, 8.70-8.80 m

Figure 25: Planorbulina mediterranensis, Sample: Core 2, 8.90-9.00 m

\section{Explanations of Plate-2}

Figure 1-2: Peneroplis planatus, Sample: Core 5,7.00-7.10 m Figure 3-4 : Hyrrokkin sarcophaga, Sample: Core 10, 5.60-5.70 m

Figure 5: Polymorphina sp. , Sample: Core 6, 8.20-8.30 m Figure 6-7 : Massilina secans, Sample: Core 10, 5.70-5.80 m Figure 8-9: Massilina secans, Sample: Core 5,7.30-7.40 m Figure 10-11: Massilina secans, Sample: Core 1, 8.50-8.60 m Figure 12-13: Massilina secans, Sample: Core 10, 5.80-5.90 m Figure 14-15: Adelosina mediterranensis, Sample: Core 2, 11.80-11.90 m Figure 16-17: Quinqueloculina seminula, Sample: Core 5, 7.60-7.70 m Figure 18-19: Quinqueloculina jugosa, Sample: Core 6, 8.40-8.50 m Figure 20-21: : Quinqueloculina disparilis, Sample: Core 9, 8.80-8.90 m Figure 22-23: Adelosina duthiersi, Sample: Core 5, 7.20-7.30 m Figure 24: Spiroloculina angulosa, Sample: Core 2, 11.50-11.60 m Figure 25: Spiroloculina excavata, Sample: Core 1, 8.70-8.80 m Figure 26, 27, 28: Cycloforina contorta, Sample: Core 8, 9.80-9.90 m Figure 29: Textularia bocki, Sample: Core 2, 11.40-11.50 m Figure 30: Pyrgo elongata, Sample: Core 8, 9.90-10.00 m 
Plate-1

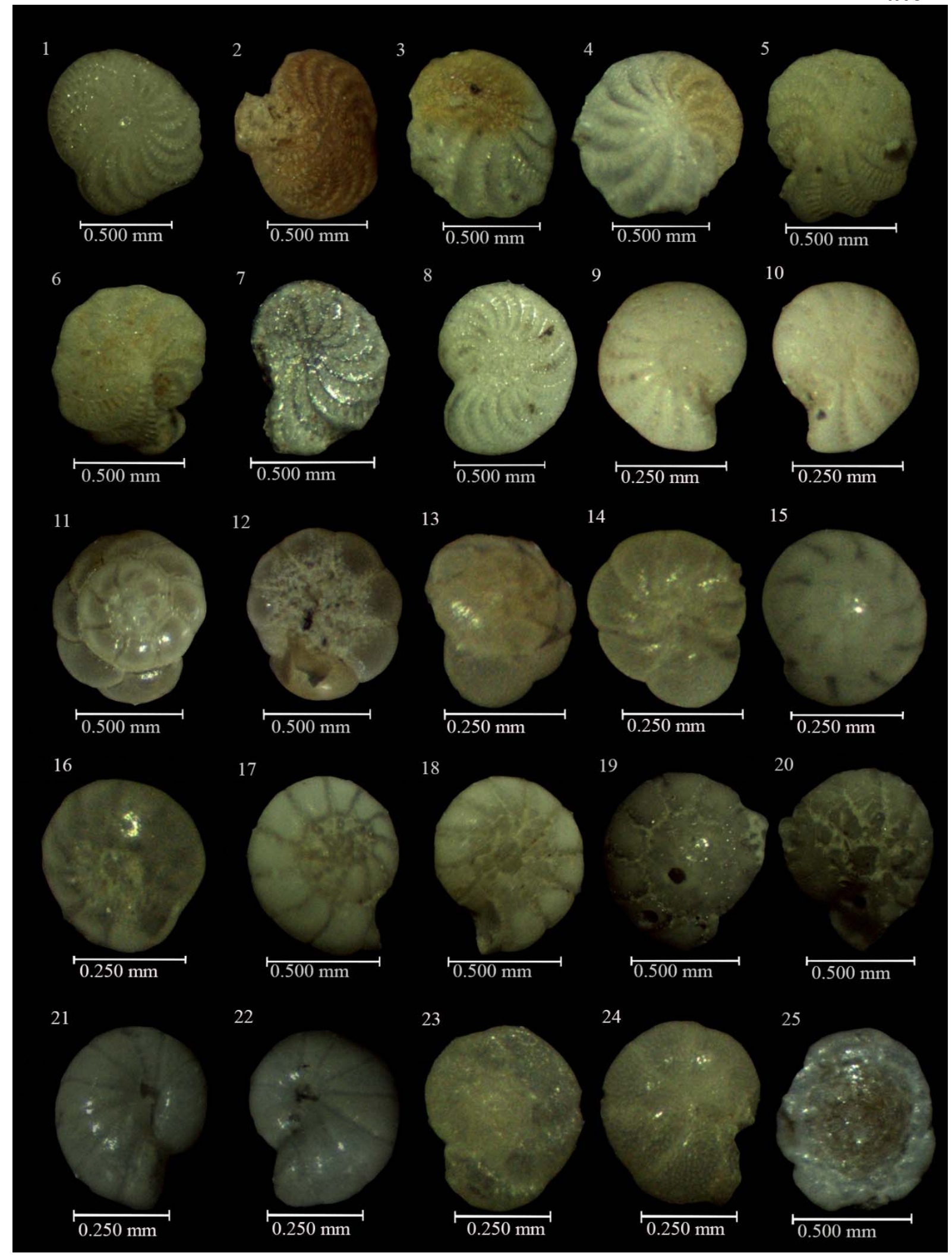


Plate-2

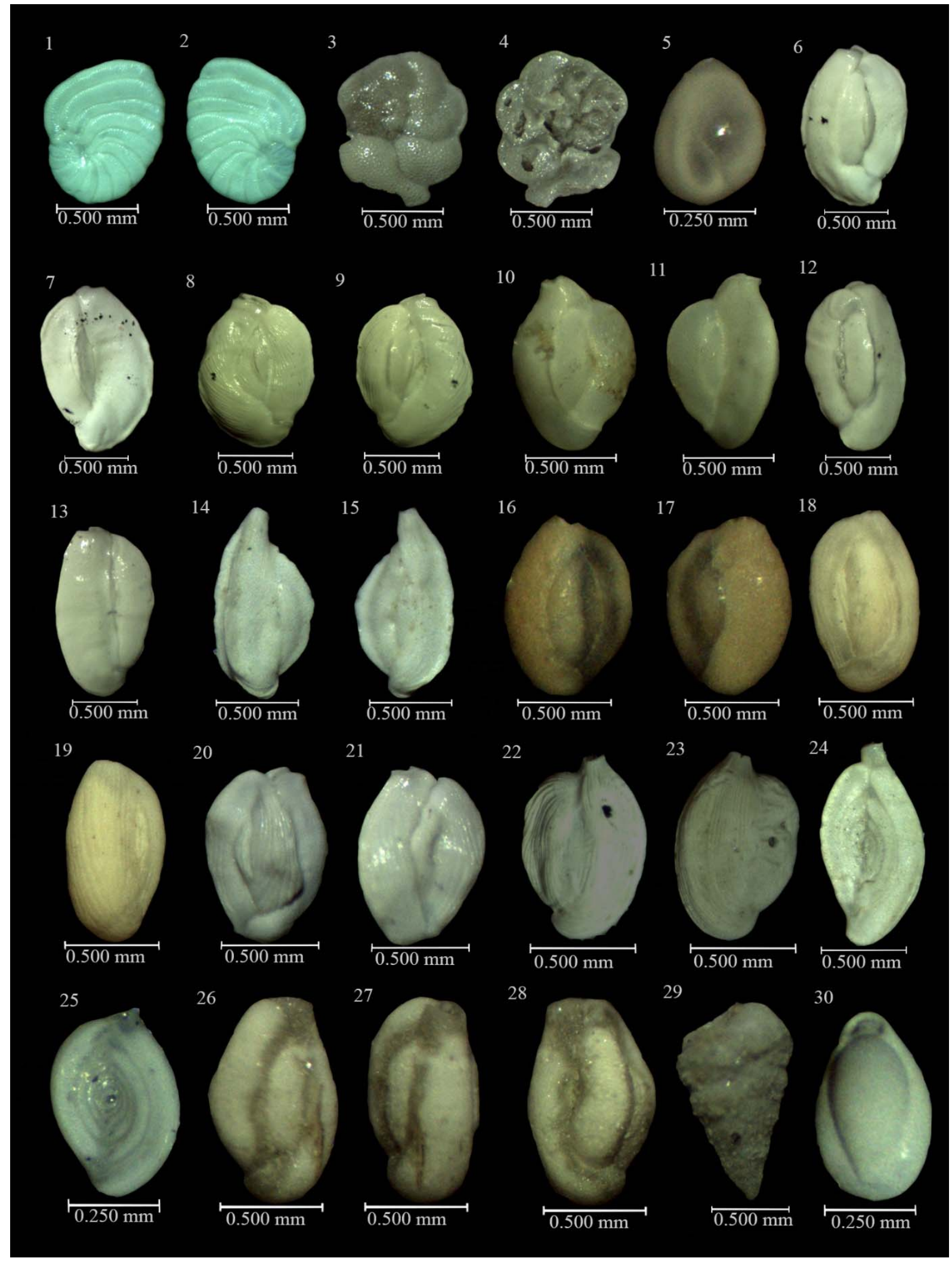

